Pedagogía y Saberes No. 50

Universidad Pedagógica Nacional

Facultad de Educación. 2019. pp. 223-225

\title{
Mactumactzá: la historia que se cuenta de las Escuelas Normales Rurales en México
}

Reseña

\section{Pinto Díaz, I. A. y Burgos, R. (2017).}

La escuela normal rural de Chiapas: memoria e imágenes. México: Universidad Autónoma de Chiapas. ISBN: 9786078459407.

Marcelo Hernández Santos*

\section{Para citar este artículo:}

Hernández, M. (2019). Mactumactzá: la historia que se cuenta de las Escuelas Normales Rurales en México. Pedagogía y Saberes, 50, 223-225.

* Doctor en Historia. Profesor-investigador de la Universidad Pedagógica Nacional, Unidad Zacatecas, México.

Correo electrónico: maruniv321@gmail.com Código oRCID: orcid.org/0000-0002-4731-0888 
$\mathrm{L}$ as Escuelas Normales Rurales (ENR) son instituciones que se crearon en México desde 1922 y se sostienen hasta la fecha. Su objetivo inicial fue formar maestros para que desempañaran sus funciones pedagógicas en el medio rural. En cada entidad federativa llegó a existir una ENR. De 1922 a 1946 el proyecto tuvo variaciones: 1) De 1922 a 1934 su nombre era ENR. 2) De 1934 a 1946 cambian de ENR a Escuelas Regionales Campesinas (ERC). 3) De 1946 hasta la fecha, conservan su nombre como ENR. La historia de estas escuelas es muy amplia y varía de región en región, pero han tenido una constante: aparecer y reaparecer durante el siglo XX y parte del XXI.

No es la intención de esta reseña contar toda la historia de las ENR, sino poner énfasis en los procesos regionales y desde ahí encontrar elementos de comparación en los proyectos productivos y de formación docente que se llevaron a cabo en estas escuelas en todo el país durante el siglo $\mathrm{xx}$, como es el caso del libro de Pinto y Burgos (2017). La historia que se ha contado de las ENR ha privilegiado los estudios desde la ciencia política, la historia, la sociología y la pedagogía. La mayoría han sido dirigidos a un público especialista, dejando de lado el gran público o a un número elevado de lectores.

Con este libro sobre las ENR, Pinto (2017) se ha convertido en una referencia obligada en la producción científica existente sobre estas instituciones ${ }^{1}$. Los últimos diez años se han producido publicaciones que abordan desde diferentes enfoques científicos lo que ha pasado en estas instituciones. Alicia Civera Cerecedo (2008), por ejemplo, las ha abordado desde el proyecto de formación y su vínculo con las condiciones económicas (generalmente precarias) de los alumnos que estuvieron en estas escuelas durante el cardenismo (1934-1940). Evangelina Terán Fuentes (2010) y Sergio Ortiz Briano (2011) las han investigado desde el movimiento estudiantil que se gestó ahí mediante una de las organizaciones de estudiantes más antiguas del continente: la Federación de Estudiantes Campesinos Socialistas de México (FECSM). Finalmente, yo mismo he abordado su historia en el libro Tiempos de reforma: estudiantes, profesores y autoridades de la Escuela Normal Rural de San Marcos frente a las reformas educativas, 1926-1984, en el que analizo y explico las reformas educativas y los modelos de formación docente que han tenido estas escuelas desde 1926 hasta 1984 (cf. Hernández, 2015).

1 Una publicación anterior de estos autores fue: Pinto Díaz, I. A. (2015). Los formadores de la escuela normal rural Mactumactzá: la configuración histórica de un modelo de formación. México: Herencia Mexicana Editorial.
Con el libro La escuela normal rural de Chiapas: memoria e imágenes me han surgido varias preguntas, por ejemplo: ¿cómo contar mejor la historia de las ENR?, ¿cuál es la forma más efectiva de hacer llegar los textos a un público no necesariamente experto, pero sí interesado en estas instituciones?, ¿las historias deben centrarse en los edificios, en la institución o en los sujetos?, ¿ se debe recurrir a los archivos o trabajar con la memoria de sus actores?, ¿es absolutamente necesario recurrir a los grandes teóricos de la historia, la pedagogía, el currículum y el análisis institucional, para documentar las investigaciones de las ENR?

Quise plantear preguntas dicotómicas para ejemplificar que este libro en realidad trasciende esta visión bipolar y resuelve, yo diría de una manera pedagógica, esta historia compleja de las ENR. Desde el subtítulo parece quedar clara la posición de los autores: Memoria e imágenes. No anteponen la memoria a la imagen; la presentan como un sano acompañamiento. Tienen claro que la memoria trabaja con las representaciones e interpretaciones del pasado de los sujetos, donde las imágenes, particularmente las fotografías, ayudan a inspirar la memoria y la evocación del pasado. Yo las veo como una herramienta para disparar la memoria, pero los autores parecen dejar al lector esta interpretación ya que por momentos las imágenes tienen un valor en sí mismas y no solo nos ayudan a recordar el pasado o a representarlo mejor, sino que se convierten en íconos del presente y del futuro. En mi opinión, ese sería el efecto de las 171 fotografías que se presentan en las 129 páginas del libro, tomadas del Archivo Histórico de la Secretaría de Educación Pública, el Archivo Histórico de Ciencias y Artes de Chiapas, el Archivo Muerto de la ENR Mactumactzá y de 14 archivos personales, en los que se destaca el de Pinto Díaz, uno de los autores de este texto.

El libro se compone de imágenes (recalco, que pueden evocar el pasado y el futuro) y su cometido principal no es contar una historia con una carga "teórica y conceptual", sino decir la historia de las ENR mostrando el "arduo trabajo de búsqueda en los archivos y las entrevistas de los actores de las ENR de Mactumactzá". El libro muestra a los historiadores profesionales el uso creativo de las fuentes para llegar al objetivo que tenemos: contar una historia a un número de lectores especialistas en el tema y para los no especialistas pero con grandes preguntas e interés en la aportación que las ENR le han hecho al país.

La historia que se cuenta de Mactumactzá es con imágenes. Los autores seleccionaron cuidadosamente las fotografías para mostrar la ENR de Mactumactzá 
en dos etapas de fundación y refundación permanente, como todas las ENR del país. La primera parte, de 1931-1935, donde se documentan los orígenes como ERC de Cerro Hueco. La segunda como ENR de Mactumactzá, que desde 1956 empezó a funcionar, después del cierre inesperado que tuvo en 1949.

Como todo libro nuevo que espera lectores, esta reseña no puede abarcar toda la historia de la ENR de Mactumactzá, Chiapas, que aún persiste. Empezaré comentando solo dos imágenes: la del principio y la del final, es decir, de forma intencional dejaré toda la trama intermedia de la historia para contarles solo retazos. El libro empieza con la imagen de la entrada a la escuela. El estado de Chiapas, México, es un paraíso; su vegetación impone y puede ser de realce más que otras cosas, sin embargo, en esta ocasión, el lema de la entrada principal, inspira (y aquí está el poder de la imagen en sí misma y no como vehículo): "Aquí estamos los mismos de siempre, no nos vendemos, no nos rendimos ¡Resistimos!”

La frase retratada, proyectada en la fotografía, lo dice todo: "los mismos de siempre". ¿Quiénes son? Los pobres, la gente del campo en espera de una oportunidad profesional para mostrar su potencial intelectual y político; los que han sido socavados y asesinados (recuerden que nos faltan 43 normalistas rurales de Ayotzinapa, Guerrero, que el Estado Mexicano desapareció en 2014); a los que se les ha vendido muy cara la educación que presume de ser pública. La historia de Mactumactzá muestra el modus operandi que los gobiernos mexicanos han perfeccionado desde lo que fue el Estado de bienestar: primero les doy, luego les quito; ahora tienen escuela e internado, ahora no. Este juego maquiavélico del Estado se ilustra y se condensa en la imagen. Pese a ese juego, en el que en vez de escuela la clase política prefiere un "laboratorio de inseminación artificial" (este fue el argumento para cerrar la ENR de Mactumactzá en 1949) para la mejora del ganado, como si el ganado, por representar dinero, fuera mejor que las personas. Pese a todas las acciones adversas, programadas sistemáticamente contra los normalistas rurales, no se han rendido, resisten. Recordemos que a esta escuela la han desaparecido cuatro veces $(1935,1942,1949$ y 2003) y ahí está, para el pueblo de México, para los pobres de Chiapas.

Es momento de ir al final del libro: la imagen que se insertó aquí es el escudo de Mactumactzá, con el lema: “Cultura, Juventud, Patria”. Así como la primera fotografía, el escudo nos lleva al pasado, cuando las ENR/ERC fueron el único medio para acceder a la "cul- tura"; a las posibilidades ilimitadas que da el dominio de los códigos lingüísticos, científicos y pedagógicos, otrora disponibles solo para unos cuantos; los que podían acceder al estudio (en el siglo XIX todavía negado para las clases populares).

De igual manera tiene sentido el lema de "juventud", porque cuasi niños (ingresaban a los doce años a las ENR/ERC) podían ser maestros, mismos que siempre fueron seleccionados de la población más vigorosa. Y la "patria", que hace referencia a las campañas antialcohólicas e higiénicas que hicieron los alumnos para civilizar a las comunidades rurales para insertarse a lo que el Estado mexicano entendía por progreso en el primer cuarto del siglo XX.

¿Qué hay en el intermedio de este libro? Revelaré parte del misterio: la desmitificación del normalismo rural maniqueo que ha sido pintado por la burguesía mexicana desde 1935 hasta 2016. Contrario a la imagen, presentada por los medios masivos de comunicación en México, que se han encargado de mostrar imágenes degradantes y deformadas de los estudiantes de las ENR, el libro muestra con rigor académico, que Mactumactzá es una escuela en donde se estudia, se hace deporte, se lucha en la FECSM; se hace patria y se ayuda a la población más necesitada. Muestra una juventud no extraviada, sana, fuerte. A un personal docente joven y diverso y por tanto rico en cultura e innovación pedagógica y de lucha. Eso ha representado Mactumactzá, eso ha sido el normalismo rural en México. Un proyecto exitoso que lo único que necesita es que se le deje ser lo que se ha planteado desde su proyecto original en 1922, sin que el Estado, con criterios políticos, intervenga.

Los autores por este texto pensaron que era un libro para ellos, para su propia memoria; para su propia institución. Olvidan que con esta labor no se han visibilizado solo ellos, sino los otros normalistas rurales y los profesores en general que viven y conviven en las 16 ENR todavía existentes en México. Pinto y Burgos no han sido egoístas, porque su libro se inscribe en un trabajo para otros y eso tiene un valor pedagógico invaluable, porque la docencia es eso: entender al otro.

Cierro invitando a la lectura de este libro y diciendo lo que significa Mactumactzá en lengua tseltal: "encima de la Montaña donde va haciendo la cuenta el abuelo". Y en zoque: "once estrellas". Si tomamos el primer lema, ¿cuál sería la cuenta que lleva el abuelo? ¿Cuál es nuestro saldo en todos estos años de normalismo rural en México? No hay que olvidar que nos faltan los 43 de la ENR de Ayotzinapa. 


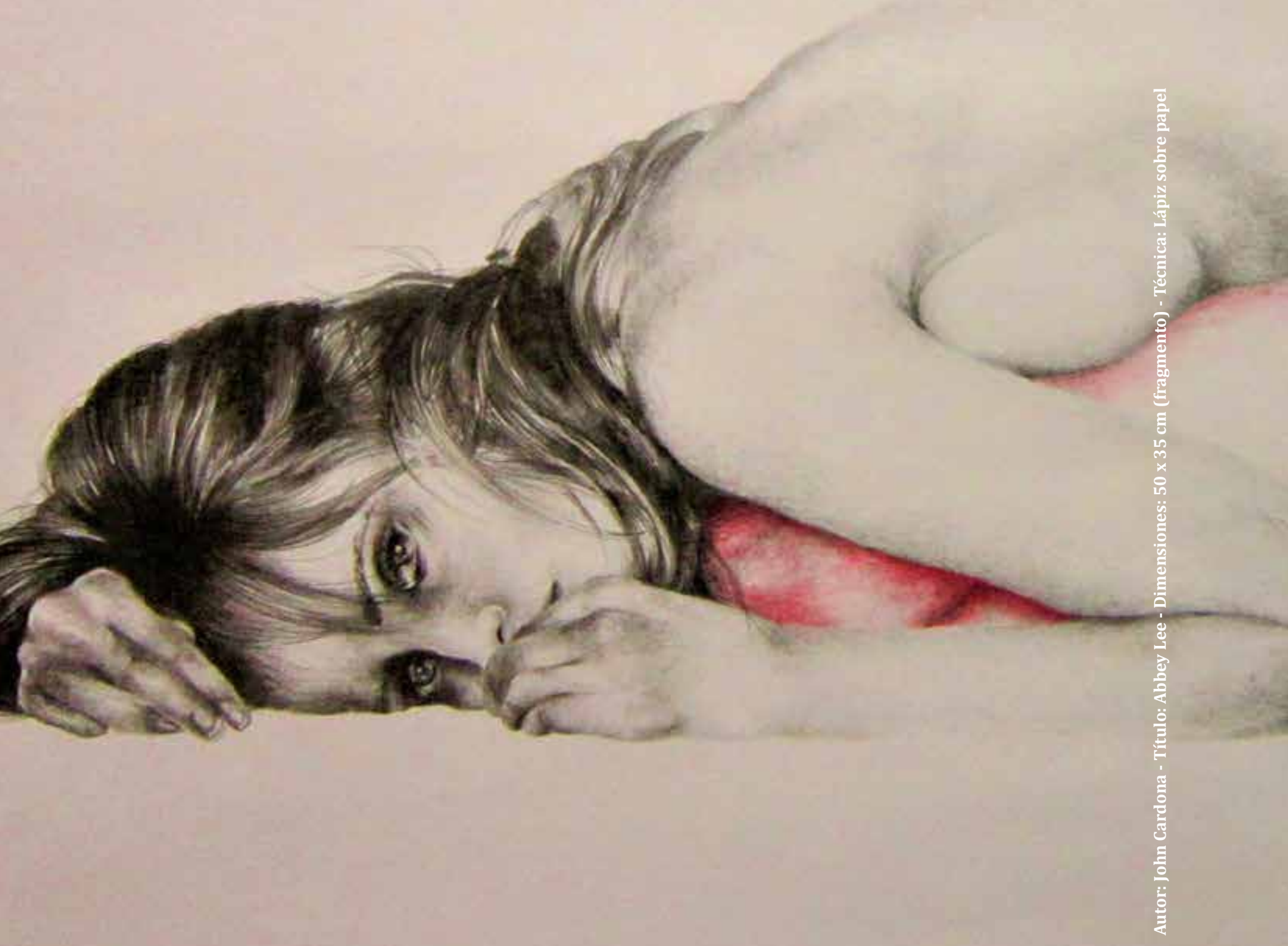

